\title{
THE EDUCATIONAL THOUGHT OF THEODORE FRELINGHUYSEN
}

\author{
BY WILLIAM J. CHUTE
}

THIS ARTICLE, based on materials in the Library, concerning the ideas of a former president of Rutgers who helped to formulate the educational policies of the institution in the middle of the nineteenth century, should have some interest at a time when the curriculum and the purposes and aims of the University's educational program are once more being examined critically. The author, William J. Chute, is a lecturer in History in the Rutgers College of Arts and Sciences.

1HEODORE FRELINGHUYSEN has found his way into history books as the social reformer, anti-slavery man, "Christian Statesman," and unsuccessful Whig vice-presidential candidate in the campaign of I 844 . His career as an educator, however, has received scant attention, although the last twenty-three years of his life were devoted to that endeavor. These years have been brushed aside as inconsequential - as the declining years of a comfortable retirement. Even in his own day his acceptance of the Chancellorship of the young University of the City of New York (now New York University) in I839 at the age of fifty-two was considered as an honorable, if unnecessary, retirement from productive public life. The consensus among New Jersey lawyers, according to his contemporary biographer, Talbot W. Chambers, was "that to put him at the head of any university was like burying him in a marble mausoleum before his time." Acquaintance with the evidence, however, disperses the idea of a comfortable retirement. One must acknowledge the missionary zeal by which Frelinghuysen lived for duty, and the fervent acceptance of what he believed to be his responsibility. Death arrived in 1862 while he was fulfilling the obligations of the office of President at Rutgers College, to which he had been elected in 1850 , and the eulogy of the trustees summarized his accomplishments on that campus. They praised him for twelve years of faithful service "... in the dignified and useful occupation of academic life ... in a severe old age."²

A broader point of view could see the beginning of his career in

${ }^{1}$ Talbot W. Chambers, Memoir of the Life and Character of the Late Hon. Theo. Frelinghuysen, LL.D. (New York, 1863), p. 57.

${ }^{2}$ Minutes of the Board of Trustees, Rutgers College, April 8, I 862. 
higher education as the natural fruition of constant concern with the problems of education which stretches back as far as his youth in Rev. Robert Finley's Classical Academy at Basking Ridge, New Jersey. While studying in the law office of his brother shortly after his graduation from Princeton in 1804 , he organized a debating society with the primary intent of "promoting the mental advancement of young men in his neighborhood." But his attention was attracted to public education in $18 \mathrm{I} 7$, when, as Attorney-General of New Jersey, he was appointed a trustee of the Common School Fund. ${ }^{3}$ The fund was to be invested, and the interest allowed to accumulate until the sum was adequate to meet the financial needs of establishing a public school system. After ten years the plan had come to a standstill, and shocked by a report of the Executive Committee of the New Jersey Bible Society on illiteracy in that state, many prominent citizens, including Frelinghuysen, became deeply concerned with the problem. This intolerable educational situation was discussed thoroughly in the Newark Sentinel of Freedom in some twenty articles signed by "A Friend of Education." These discussions might easily have come from Frelinghuysen's pen, in cooperation with others. ${ }^{4}$

Whether Frelinghuysen had a hand in the I 828 articles or not, similar ideas and purposes were expressed in 1838 in a pamphlet entitled "An Address to the People of New Jersey on the Subject of Common Schools," issued by the Society of Friends for Education, and to which he among others signed his name. The support of education was placed squarely on universal natural law-the high principle that God has ordained that knowledge was the universal right of man; that a quest of knowledge should be the duty of man; that extension of knowledge should be of universal interest to man. The failure to support education limits man's capacity to understand truth, "undermining the foundations of government, weakening the hold of society, and preparing the way for that unsettling and dissolving of all human institutions, which must result in anarchy and ruin." The penny-pinchers who held that the support of schools was too expensive, were met with the sociological argument that there was a definite connection between ignorance and crime, and that it was

${ }^{3}$ David Murray, History of Education in Nequ Jersey (Washington, 1899), p. 155.

${ }^{4}$ Nelson R. Burr, Education in New Jersey (Princeton, 1 942), p. 249. Writing from Princeton, Burr does not hesitate to give full credit for these articles to Robert Baird without stated proof, although Murray suggests that they might have been written by both men. 
cheaper for the state government to provide an agency of prevention. "Shall there be provision to punish only," the report asked, "and none to prevent? Shall the only offices in which the state is known, be those of jailor and executioner? Shall she content herself with the stern attribute of justice, and discard the gentler ministries of mercy?" Let New Jersey "be the state of common schools, academies and colleges, the educating state, the nursery of freemen."

Frelinghuysen's deep anxiety for the improvement of public schools was not confined solely to his native state. In the next year his name was found on the letterhead of The American Common School Society in the capacity of Vice-President. The headquarters of this organization in New York City was the clearinghouse for statistics, and other information that might be desired by advocates of common schools throughout the nation. It had distributed free of charge 8,000 copies of a design for a model schoolhouse, and had sold I00,000 copies of a publication called The Common School Almanac, a repository of various kinds of information. ${ }^{B}$

But Frelinghuysen's mind was too broad to be confined within the compass of state education. He defended the innate capacity of the Negro to absorb education. As a member of the American Colonization Society, then under attack by a group of anti-slavery men intent on freeing the slave immediately by political action, he argued that education must precede emancipation. The free Negro in the United States, living in a degraded condition and excluded from the privileges of freemen, must be educated in a friendly environment of his own making. For this reason Frelinghuysen supported the colonization of Liberia in Africa. "What can there be of unkindness, in sending children home to the land of their fathers, and there nourishing them by the lights of science, religion and liberty." This plan was not supported by benevolent men in order to rid the nation of an inferior, degraded type of humanity, as some critics asserted. Divorced from his lowly position in society, and given the proper environment, the Negro would prove himself capable of absorbing the best in education. "His mind expands, as his condition improves," Frelinghuysen assured his readers, a fact verified by the extraordinary success of the African colony.

${ }^{5}$ Reported in The Christian Intelligencer, April 7, 1838 .

${ }^{6}$ The Christian Intelligencer, January $24,1839$.

7 "Review of Anti-Slavery Publications in Defense of the American Colonization Society," Literary and Theological Review, I, 68, 1833 . 
A letter written in June of 1836 to Mr. Reuben D. Turner, a Virginian intent upon leading the Young Men's Colonization Society of New York, substantiates his interest in Negro education, and indicates his conviction that belief in these people should be strengthened with financial support. ". .. We must, by schools and colleges there, render the colonies hopeful spots, toward which the colored man will turn his eye and his heart from the ends of the earth, when he thinks of himself and his children." "What he believed that education should consist of was made clear the next year in his speech before the American Society for the Promotion of Education in Africa. It was to endow them with the benefits of a Christian training which would have both practical and intellectual aspects. Schools were to be established to train the colonist gradually in the elementary branches of practical knowledge-agriculture, use of tools, and navigation. Those who showed promise were to have further training in the higher branches of learning. And Frelinghuysen's constant concern with religious education caused him to emphasize that the purpose should be "to spread open to their untutored minds the lessons of eternal truth, and point perishing millions to provisions and hopes, full of immortality." His broad purpose was the advancement of all Africa.

Frelinghuysen's ideas on higher education were expressed clearly in his two inaugural addresses, ${ }^{10}$ several addresses to students, and the few brief letters which have survived in the pages of Chambers' biography. They could scarcely win him a place on the pedestal of original thought, but like Lyman Beecher's favorite type of preacher, his ideas stood out like a rabbit's ears so that people could grab hold of them. Catalogued easily as belonging to the traditional classical-religious-discipline curriculum, they gave no comfort to the large group of mourners after the eighteenth-century system of classical education, who felt that because of the inroads made upon it by modern science, too much had already been lost. "The jealousies toward the colleges," he replied, "arise from a misapprehension of the nature and tendencies of true science." 11 Yet he supported the conservative reaction, expressed by the Yale Report of $\mathrm{I} 828,{ }^{12}$ to the liberal opin-

\footnotetext{
${ }^{8}$ June 27, 1836, printed in The Christian Intelligencer, August 6, 1836 .

9 The Christian Intelligencer, March 4, I837.

${ }^{10}$ University of the City of New York, 1839; Rutgers College, $185^{\circ}$

11 Inaugural address at Rutgers College, i 850.

${ }^{12}$ In this famous report on the purpose of college training President Jeremiah Day
} 
ions of Ticknor of Harvard which would broaden the curriculum, and he led in the denunciation of Jefferson's program at the University of Virginia, where "a set of pretty wild fellows" chose their own studies, used no textbooks, and were not required to attend chapel for daily prayers. ${ }^{13}$ It was as a champion of the traditional scheme against the cavalier doctrines of Jefferson that he was widely known in his day. ${ }^{14}$

In the second third of the nineteenth century the mental atmosphere of society was saturated with religious soul-searching, and the mind of Frelinghuysen had absorbed as much of this attitude as it could possibly hold. It was a period that preferred a minister in the role of a college president, and if Frelinghuysen was no reverend, he was certainly a deacon, and the whole purpose of his life was the pursuit of a perfect understanding of man's duties and obligations to God. One would not be far from the truth in viewing his acceptance of an educational post as missionary work. In fact in his thinking one finds no distinction made between "soul" and "mind"; to him they were synonymous terms. The mind was being rigorously trained not merely for an earthly existence, but for eternity. Its apparent libertine tendencies were to be vanquished by regular, systematic, and severe study to awaken the faculties of the mind which lay in a dormant state. "God has endowed man with immortal faculties, capable of infinite improvement, ${ }^{15}$ he insisted, and the best system of education was the one which threw the youth upon his own resources, testing his strength, and bringing him "to feel that he has a power within him which can reason, combine, compare, and judge; and that under heaven it rests with his own will, whether these powers shall or not

wrote: "The two great points to be gained in intellectual culture, are the discipline and the furniture of the mind; expanding its powers, and storing it with knowledge." See, "Original Papers in Relation to a Course of Liberal Education," American Journal of Science and Arts, Vol. I5 (January, 1829), p. 301. Frelinghuysen added: The refinement of taste and the development of a sense of duty and responsibility to one's fellow men and one's country. (Rutgers Inaugural Address, $185^{\circ}$.)

13 "Henry Barnard Comments on the University of Virginia and its Students, 1833" in Edgar W. Knight (Ed.), A Documentary History of Education in the South Before 1860, Vol. III (Chapel Hill, 1952), pp. 266-267.

${ }^{14}$ R. Freeman Butts \& Lawrence A. Cremin, $A$ History of Education in American Culture (New York, 1953), p. 227; for actual use of his ideas against this system see, Frederick A. P. Barnard, Report on a Proposition to Modify the Plan of Instruction in the University of Alabama (New York, I 855, p. 86).

${ }^{15}$ Inaugural address at Rutgers College, 1850. 
meet their exalted destinies." ${ }^{16}$ The success each student achieved in this sink-or-swim procedure was determined by individual recitation in the college class, and as the most difficult subjects were the best, the ancient languages and mathematics stood at the core of the system. This idea was expressed as early as I 834 in a letter to a young friend. "I am happy to learn from your letter that you are at hard study. I know that it is wholesome. The brain needs action. It is like a flint-to have fire you must strike it. ${ }^{17}$

He was also not averse to using physical analogies to advance his favorite point of view. In the same letter, using the vigor and brawn of the forgeman as an illustration, he asked "what gave him all this, but swinging the ponderous sledge. Once it made him pant to wield it; now he can toss it as a plaything. So it is with the mind. If you wish to give it strength, and tone, and compass, you must put its power to the trial, bring them out to stern, severe, and laborious exercise."

Frelinghuysen again and again laid strong emphasis on the study of languages as mental discipline, and although he believed that any tongue, the most primitive or the most highly elaborate, was profitable for this purpose, he was convinced that the ancient languages were superb. Not only did they exercise the mind in a most taxing manner, but they improved the memory, refined the taste, sharpened attention, and matured judgment. For these reasons alone, they were worth the time devoted to them. "A single word will challenge serious and often severe investigation ... in all this, the mind healthfully grows. The man has been in this way taught to investigate, to reason, and to unravel perplexities. ... He becomes a wiser and a stronger man, better fitted to grapple with the reality before him." "18

Mathematics, admitted by schoolboys throughout history to be the one frightful incubus which crushed pleasure out of their academic years, was to Frelinghuysen, a subject that aroused the fondest and most pleasing emotions. Its honored place in the curriculum of higher education was accepted wholeheartedly and without question. Its acknowledged power improved and sharpened all the functions of the mind, and, in particular, endowed it with the power to recognize

${ }^{16}$ Inaugural address at University of the City of New York, 1839.

${ }^{17}$ Chambers, op.cit., p. 202.

${ }^{18}$ Frelinghuysen's Baccalaureate Address, June 17, 1861, in The New Brunswick Fredonian, Thursday, July 4, 1861. 
precise detail, to make fine distinctions, and perceive relationships in reasoning, as well as to polish the gift of thinking in the abstract. Nevertheless it possessed the quality of poetry. The student soon learned that, contrary to his predisposition to consider the subject dull and dry-as-dust, a dip into this draught was an intoxicating adventure which established a strong desire to drink in it deeply. "We come to learn and rejoice" Frelinghuysen informed the students at Rutgers, "to perceive that by the aid of that law which takes the measure of the circle - the square and the angle-man has 'roamed among the stars, rode on the winged lightning, and swept the long track of day.' " Its additional utility was in laying the firm foundation of one of the sure roads to truth-the avenue of logic. ${ }^{19}$

Mathematics was the handmaid of all the sciences, and these sciences demonstrated the wonder workings of the "Wonder Working Maker." Was it not the Bible shepherd boy who grew up to be a king who told the world that "the heavens declare the glory of God and the firmament showeth his handiwork."

Chemistry needed no defense because it had proved its value to American businessmen. But pointing to Natural Science as a whole, he maintained that, contrary to the words of its critics, it upheld the Bible by demonstrating that the "Author of Nature is the God of the Bible." Rather than conflicting with revealed religion, it, on the contrary, supported its great truths.

The administrative duties of the nineteenth century college president were seldom heavy or time consuming, and he was expected to assume some teaching assignments. The course was usually Christian Evidence, although a student of American higher education could point immediately to several notable exceptions. Frelinghuysen was one of these..$^{20}$ His specialty was Constitutional Law and Politics. This was considered to be one of the "furniture" courses by which the disciplined mind was brought to bear upon definite problems of human relations. In the terms of Frelinghuysen's definition it was "that branch of education which regards the political relations of every citizen to the government of his country," with strong stress on the

${ }^{19}$ Inaugural address at Rutgers College, 1850.

${ }^{20}$ Even Frederick A. P. Barnard, a distinguished physicist, during his early years of presidency of Columbia College in the I 860's was obliged to teach Christian Evidence, an obligation which he had escaped in his previous position as Chancellor of the University of Mississippi. See Columbia College Annual Report, 1866. 
relationship that liberty has to one's responsibilities. ${ }^{21}$ The key words of his approach were duty and responsibility, without which freedom and liberty were but hollow conceptions. In fact his thinking on politics was an obvious transposition of his religious ideas of man's responsibilities to God into the garment of political thought. "The fundamental law of our constitution," he averred, making men "free almost as the air they breathe, enjoying government of their choice, dependent on public opinion for its existence and powers, the conclusion is clear that unless this public will be under the control of moral principles based on religious obligation, it is doomed to bitter disappointment." ${ }^{22}$ The political purpose of education, therefore, was the influence which the educated man might bring to bear upon public opinion to direct it to stable, thoughtful conduct in the pursuit of righteous government. Frelinghuysen's imagination could conjure up no more pitiable creature in society than the person whose mind had been shaped by the rigors of disciplined education, trained to think and to be aware of his "immortal powers," and who chose to sit down ignobly "to do nothing; and, of course, to be nothing." ${ }^{23} \mathrm{He}$ had shirked his obligations as an educated man. The study of government and politics had the additional purpose of cultivating the spirit of patriotism - "the lover of country in spite of her faults"and should kindle the ambition to "stand by our country and the Union, shoulder to shoulder, and heart to heart." "24

Finally, Frelinghuysen averred: "The truth is, an educated man of upright purpose is a public blessing, put him where you may. Look into any retirement, remote on a hill or valley where he dwells and you will perceive the beneficient influence spreading from him in a thousand lines. Agriculture, commerce, and manufactures, all partake of it."25

\footnotetext{
${ }^{21}$ Inaugural address, Rutgers College, 1850.

22 Ibid.

${ }^{23}$ Baccalaureate Address, Rutgers, July 25, 1854 .

24 Ibid.

${ }^{25}$ Inaugural address, Rutgers College, 1850.
} 